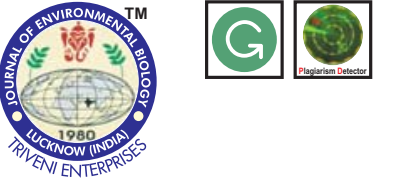

\title{
Effect of environmental factors on growth and enzyme production of cold adapted bacteria from water and sedi- ment of Kongsfjord, Ny-Alesund, Arctic
}

\section{Authors Info \\ S. Salam ${ }^{1}$, S. Lekshmi', R. Silvester ${ }^{1 *}$, K.P. Krishnan ${ }^{2}$, A.V. Saramma ${ }^{1}$ and A.A.M. Hatha ${ }^{1}$ \\ ${ }^{1}$ Department of Marine Biology, Microbiology and Biochemistry, Cochin University of Science and Technology, Cochin-682 022, India \\ ${ }^{2}$ National Centre for Antarctic and Ocean Research, Head Land Sada, Vasco-da-Gama, Goa-403 804, India \\ ${ }^{*}$ Corresponding Author Email : sanasilvester@gmail.com}

Key words

Bio-prospecting,

Cold-adapted bacteria,

Hydrolytic enzymes,

Psychrotolerant bacteria

Publication Info

Paper received: 07.01 .2016

Revised received : 23.05 .2016

Re-revised received : 20.10 .2016

Accepted : 01.12.2016

\section{Abstract}

Aim : The Arctic region has several distinct habitats which makes Arctic a potential region for identifying novel microbial extremophiles. The main objective of the study was to find out the effect of environmental factors such as temperature, $\mathrm{pH}$ and salinity on the growth and hydrolytic enzyme production capabilities of psychrotrophic bacteria from the water and sediment of Kongsfjord, Arctic.

Methodology : One hundred and twenty two bacterial isolates from water and sediment of Kongsford $\left(79^{\circ} 58^{\prime} \mathrm{N}, 12^{\circ} \mathrm{E}\right)$ was obtained for the study. Bacterial isolates were inoculated on ZoBell's Marine medium to study the effect of temperature $\left(4^{\circ} \mathrm{C}, 20^{\circ} \mathrm{C}\right.$ and $\left.37^{\circ} \mathrm{C}\right), \mathrm{pH}(2-13)$ and salinity $(0.5-4 \mathrm{M})$ on growth. Effect of temperature on production of extracellular enzymes such as amylase, gelatinase and lipase were checked by plate assay.

Results : All the isolates showed growth at $4{ }^{\circ} \mathrm{C}, 20^{\circ} \mathrm{C}$ and $37^{\circ} \mathrm{C}$; signifying that these isolates were psychrotolerants rather than true psychrophiles. More than $50 \%$ of isolates from both water and sediment samples showed growth at wide $\mathrm{pH}(2-11)$ range. Salinity tolerance for majority of isolates (54\%) of water was $3 \mathrm{M}$ and that from sediment varied from $0.5 \mathrm{M}$ to $4 \mathrm{M}$. Majority of the isolates were capable of producing lipase, followed by gelatinase and amylase. Nearly, all the isolates from water and sediment showed lipolytic activity at $37^{\circ} \mathrm{C}$ and more than $70 \%$ of isolates at $4^{\circ} \mathrm{C}$.

Interpretation : All the isolates produced one or more enzymes; amylase, lipase or protease at $4{ }^{\circ} \mathrm{C}$ and (or) $37^{\circ} \mathrm{C}$ and showed growth at wide $\mathrm{pH}$ range and exhibited high salinity tolerance. Thus, the bacteria present in water and sediments of Kongsford are a potential source of novel hydrolytic enzymes, especially lipase that have wide applications in biotechnology, medicine, agriculture, etc

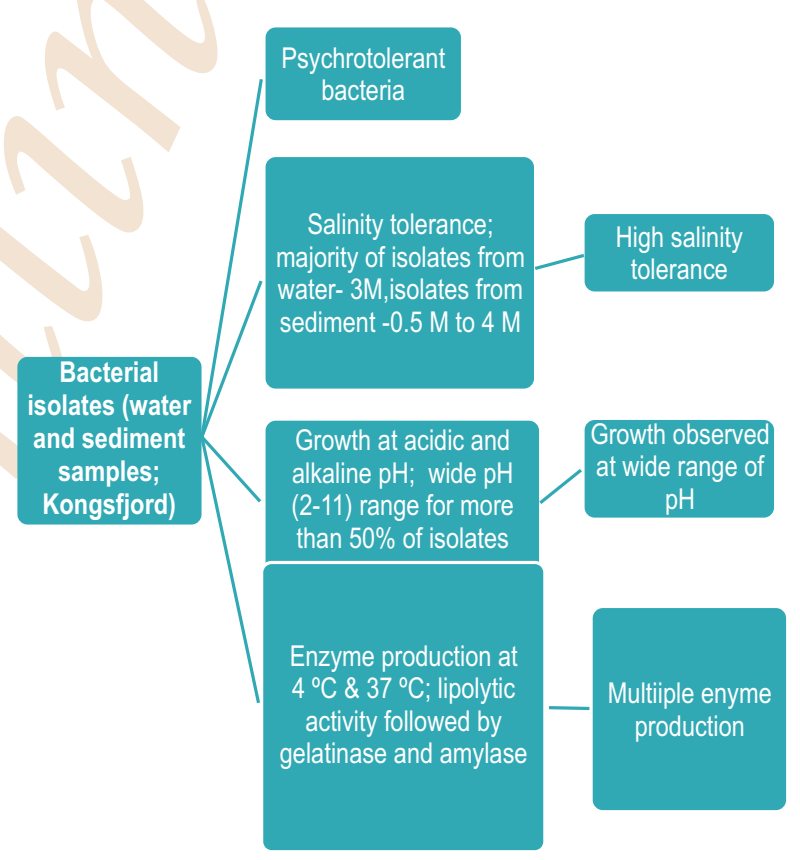




\section{Introduction}

The Arctic fjord, Kongsfjorden located off the west coast of Spitsbergen is considered as a model site for climate change studies in the Arctic (Wlodarska-Kowalczuk and Weslawski, 2001). In addition, it is also regarded as the main European site for monitoring the Arctic biodiversity (Hop et al., 2002). The Arctic region has several distinct habitats, which makes it a potential region for identifying novel microbial extremophiles (Reddy, 2009). The microbial extremophiles are the dominant life forms of the polar environments; able to survive in the extreme polar environments like freezing temperatures and repeated freezethaw cycles, desiccation, high or low levels of salinity or $\mathrm{pH}$ etc. (Hoover and Pikuta, 2010).

The major portion of the Earth's biosphere consists of microorganisms that live in cold environments (Kuddus, 2015). Psychrophiles and psychrotrophs from polar environment have potential for novel biotechnological applications which has resulted in bioprospecting of bacteria from sediment and water of Kongsfjord for cold-active enzymes (Groudieva et al., 2004; Teske, 2011; Neethu et al., 2012; Prasad et al., 2014). They have provided a multitude of potential applications in biotechnology, medicine, agriculture, etc. (Feller and Gerday, 2003; Podar and Reysenbach, 2006). Furthermore, the ability of psychrotrophs to grow over a wide range of temperatures, $\mathrm{pH}$ and salinity makes them even more versatile. The proper understanding of the dynamics of microbial life of polar region supplements the newly emerging field of Astrobiology because polar environments of Earth provide the best terrestrial analogues for frozen world of Solar System bodies (Hoover and Pikuta, 2010).

Most of the cold-active enzymes have high catalytic efficiency at low and moderate temperatures at which homologous mesophiles are inactive (Kuddus, 2015). The enzymes from psychrotrophs are only recently exploited, and there is still a lot to study about its future in various applications. Regular screening of new microorganisms for their cold active and thermo-stable enzymes will open novel and simpler routes for the synthetic processes.

In this study, psychrotrophic bacteria from the water and sediment of Kongsfjord were tested for the effect of environmental factors such as temperature, $\mathrm{pH}$ and salinity on their growth and hydrolytic enzyme production capabilities.

\section{Materials and Methods}

Sampling site and method of sampling: The water and sediment samples were collected from selected stations (four stations) in Kongsford at Ny Alesund region $79^{\circ} 58^{\prime} \mathrm{N}, 12^{\circ} \mathrm{E}$ ) of
Norwegian Arctic during the Indian Arctic Summer Expedition, 2009 (Fig 1). Two water samples (surface and bottom water) and one sediment sample were collected from each of the stations. Water samples were collected using Niskin Sampler and sediment samples using Van Veen Grab (Model 12.320, KC, Denmark), on board Research Vessel 'Teisten' and were stored in sterile Schott Duran bottles and polythene bags, respectively. The station characteristics such as temperature, salinity and depth were analyzed using CTD instrument, Model SD204 (SAIV A/S Environmental Sensors and Systems, Norway). Samples were stored at $4{ }^{\circ} \mathrm{C}$ for further laboratory analysis. Bacteria were isolated and characterized (Hatha et al., 2013) from water and sediment samples. These characterized isolates were obtained for performing the current study. The effect of environmental factors such as temperature, $\mathrm{pH}$ and salinity on growth and enzyme production was studied with these characterized isolates from water and sediment.

Effect of temperature, salinity and $\mathrm{pH}$ on growth : To check the effect of temperature on the growth of bacterial isolates, three sets of plates were streaked aseptically, one set was incubated for 5 days at $4{ }^{\circ} \mathrm{C}$, and other two sets were incubated for 2 days at 20 ${ }^{\circ} \mathrm{C}$ and $37^{\circ} \mathrm{C}$. Growth was observed within two days in plates incubated at $20^{\circ} \mathrm{C}$ and $37^{\circ} \mathrm{C}$, whereas plates incubated at $4{ }^{\circ} \mathrm{C}$ required a prolonged period of incubation to document the growth.

To study the growth at different salt concentrations, ZoBell's marine agar plates were prepared using different concentrations of $\mathrm{NaCl}(0.5-4 \mathrm{M})$ and bacterial isolates were streaked aseptically. The plates were incubated for 4-14 days at $20^{\circ} \mathrm{C}$, optimum temperature for growth (Morita, 1975) and growth at different concentrations of $\mathrm{NaCl}$ were observed.

Growth of isolates in acidic $\mathrm{pH}$ (2-7) and alkaline $\mathrm{pH}$ (713) were checked by adjusting the $\mathrm{pH}$ of ZoBell's Marine medium using $1 \mathrm{~N} \mathrm{HCl}$ and $1 \mathrm{~N} \mathrm{NaOH}$, respectively, and inoculated plates were incubated at $20^{\circ} \mathrm{C}$ for $4-14$ days. For checking growth at $\mathrm{pH}$ above 12 and below 2, Zobell's Marine broth was used because agar did not solidify at this $\mathrm{pH}$ and change in turbidity of broth was documented as growth.

Effect of different temperature on hydrolytic enzyme production : Extracellular enzymes such as amylase, gelatinase and lipase were checked by plate assay. Cultures were spot inoculated on sterile nutrient agar plates supplemented with $1 \%$ starch, $1 \%$ gelatin and $1 \%$ tributyrin and incubated at $4{ }^{\circ} \mathrm{C}$ and 37 ${ }^{\circ} \mathrm{C}$ for 2-5 days. A change in the opacity of the medium around the colony indicated lipase activity. Clear zones around the colonies on addition of mercuric chloride solution and Gram's iodine 
solution indicated gelatinase and amylase activity, respectively.

Statistical analysis : Two-way ANOVA was performed in MS Excel to check for any significant difference in growth of isolates from water and sediment at different $\mathrm{pH}$ and salinity ranges. Enzyme production by water and sediment isolates at two different temperatures was also analysed statistically using twoway ANOVA.

\section{Results and Discussion}

On studying the effect of temperature on the growth of one hundred twenty two (43 from water and 79 from sediment) isolates revealed that all of them exhibited growth at $4{ }^{\circ} \mathrm{C}, 20^{\circ} \mathrm{C}$ and $37^{\circ} \mathrm{C}$ indicating that all the isolates were psychrotolerant. Similar psychrotolerant bacteria capable of growing between $4^{\circ} \mathrm{C}$ and $37^{\circ} \mathrm{C}$ were reported earlier from Kongsfjord and nearby fjord (Reddy et al., 2009; Srinivas et al., 2009; Rasol et al., 2014; Neethu et al., 2015). This can be an advantage in survival strategy at low temperature biotopes like Polar Regions, which are prone to changing climatic conditions. Most Arctic isolates are not strict psychrophiles but psychrotolerant microorganisms (Helmke and Weyland, 2004). Studies have also shown that psychrotolerant bacteria numerically dominate in seawater and sediments with psychrophilic bacteria being rarely isolated (Helmke and
Weyland, 2004). Tan and Ruger (1991) reported a numerical dominance of psychrotolerants in Southern Fram Strait, Arctic Ocean. The influence of warm Atlantic water on Fram Strait and then to Kongsfjord could be the possible reason for the selection of psychrotolerant rather than true psychrophiles in the study area. A study by Shukor et al. (2009) reported isolation of a psychrophilic diesel-degrading bacterium from Antarctic soil and suggested that it was useful in biodegradation in the polar region. The isolates exhibited a low optimum temperature at $10{ }^{\circ} \mathrm{C}$ for growth when diesel was supplied as sole carbon source. This revealed the psychrophilic-psychrotolerant nature of the isolates. Psychrotrophic bacteria respond to temperature downshifts by a lag period before growth resumes at a rate characteristic of the new temperature (Bayles et al., 1996; Michel et al., 1997). All the isolates incubated at $4{ }^{\circ} \mathrm{C}$ showed slow growth, and a longer period of incubation was required to document the growth.

Many researchers (Jankowska et al., 2005; Teske, 2011; Hatha et al., 2013) had reported bacterial diversity, biomass and abundance in water and sediment samples of the fjord previously. The growth of isolates collected from water at different $\mathrm{pH}$ is shown in Table 1. They could tolerate a wide range of $\mathrm{pH}$. Among these isolates, $54 \%$ showed growth at $\mathrm{pH}$ range $2-13,12 \%$ at $\mathrm{pH}$ range $3-13,30 \%$ at the range $4-13$ and $2 \%$ each at $\mathrm{pH}$ range $5-13$

Table 1 : Effect of $\mathrm{pH}$ and salinity on growth of cold adapted bacteria isolated from water of Kongsfjord

\begin{tabular}{|c|c|c|c|c|c|c|c|c|c|}
\hline Stations & $\begin{array}{l}\text { Isolate } \\
\text { No. }\end{array}$ & Identity & $\mathrm{pH}$ & $\begin{array}{l}\mathrm{NaCl} \\
\text { tolerance (M) }\end{array}$ & Stations & $\begin{array}{l}\text { Isolate } \\
\text { Number }\end{array}$ & Identity & $\mathrm{pH}$ & $\begin{array}{l}\mathrm{NaCl} \\
\text { tolerance (M) }\end{array}$ \\
\hline \multirow[t]{5}{*}{ Station 1} & & & & & Station 3 & & & & \\
\hline & 1 & Pseudomonas & $6-13$ & 3 & & 23 & Staphylococcus & $3-13$ & 3 \\
\hline & 2 & Coryneforms & $2-13$ & 4 & & 24 & Staphylococcus & $2-13$ & 3 \\
\hline & 3 & Streptococcus & $2-13$ & 4 & & 25 & Aeromonas & $2-13$ & 3 \\
\hline & 4 & Micrococcus & $2-13$ & 4.5 & & 26 & Pseudomonas & $4-13$ & 2.5 \\
\hline \multirow[t]{19}{*}{ Station 2} & & & & & & 27 & Pseudomonas & $3-13$ & 3.5 \\
\hline & 5 & Streptococcus & $4-13$ & 3.5 & & 28 & Cytophaga/Flavobacteria & $3-13$ & 4 \\
\hline & 6 & Staphylococcus & $4-13$ & 3.5 & & 29 & Staphylococcus & $2-13$ & 2.5 \\
\hline & 7 & Staphylococcus & $4-13$ & 3 & & 30 & Acinetobacter & $2-13$ & 3 \\
\hline & 8 & Staphylococcus & $4-13$ & 3 & & 31 & Coryneforms & $2-13$ & 3.5 \\
\hline & 9 & Coryneforms & $4-13$ & 3 & Station 3 & & & & \\
\hline & 10 & Streptococcus & $4-13$ & 3.5 & & 32 & Coryneforms & $4-13$ & 4 \\
\hline & 11 & Coryneforms & $4-13$ & 4 & Station 4 & & & & \\
\hline & 12 & Enterobacteriacea & $4-13$ & 4 & & 33 & Coryneforms & $2-13$ & 3 \\
\hline & 13 & Coryneforms & $2-13$ & 4 & & 34 & Enterobacteriaca & $4-13$ & 3 \\
\hline & 14 & Coryneforms & $2-13$ & 3 & & 35 & Coryneforms & $2-13$ & 3 \\
\hline & 15 & Enterobacteriacea & $4-13$ & 2.5 & & 36 & Coryneforms & $4-13$ & 3 \\
\hline & 16 & Coryneforms & $4-13$ & 4 & & 37 & Coryneforms & $2-13$ & 2.5 \\
\hline & 17 & Coryneforms & $4-13$ & 2.5 & & 38 & Staphylococcus & $2-13$ & 4.5 \\
\hline & 18 & Alcaligenes & $4-13$ & 2.5 & & 39 & Coryneforms & $2-13$ & 3 \\
\hline & 19 & Bacillus & $2-13$ & 4 & & 40 & Aeromonas & $2-13$ & 3 \\
\hline & 20 & Staphylococcus & $2-13$ & 2.5 & & 41 & Staphylococcus & $4-13$ & 4 \\
\hline & 21 & Staphylococcus & $2-13$ & 4 & & 42 & Pseudomonas & $2-13$ & 4 \\
\hline & 22 & Staphylococcus & $2-13$ & 3 & & 43 & Pseudomonas & $2-13$ & 4 \\
\hline
\end{tabular}




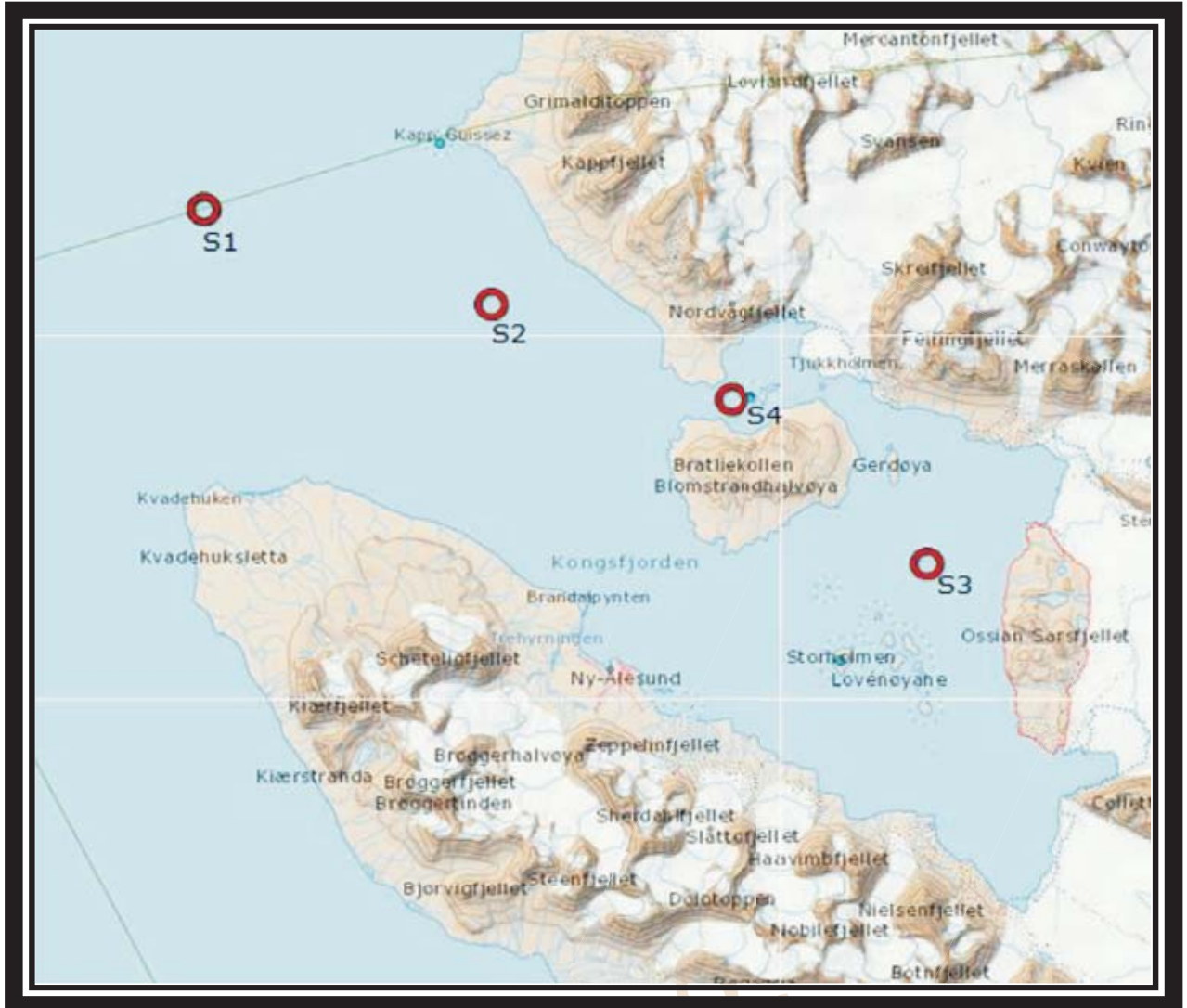

Fig. 1 : Map showing four sampling sites (S1, S2, S3 and S4) along Kongsfjord
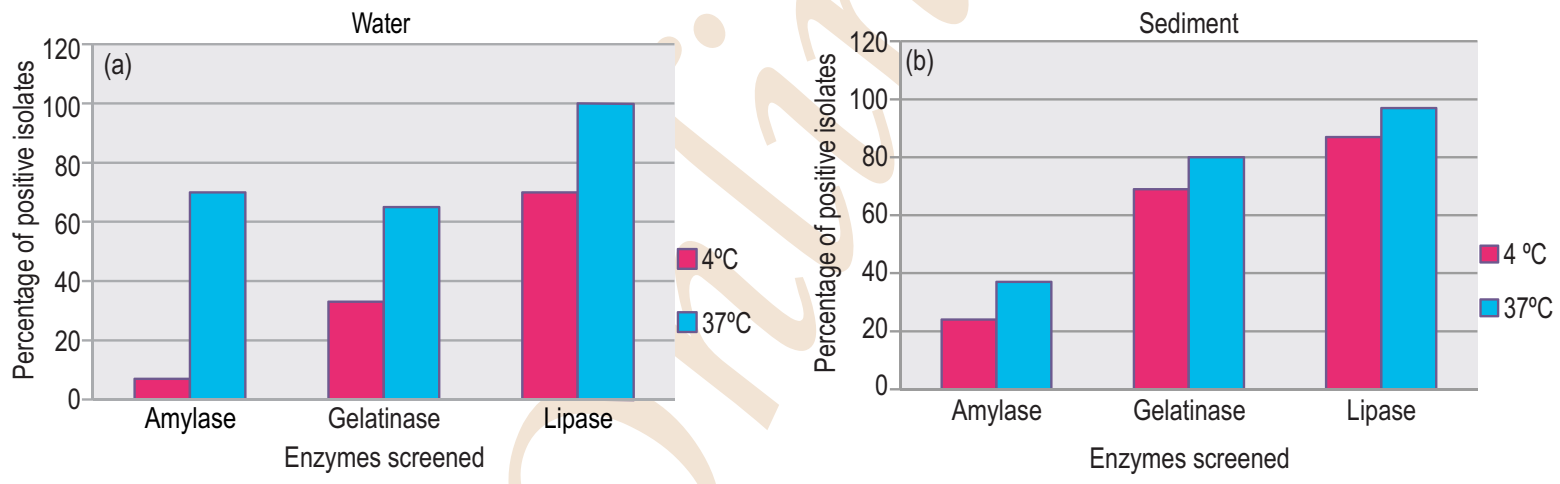

Fig. 2 : Capability of isolates to produce hydrolytic enzymes (amylase, lipase and gelatinase at $4^{\circ} \mathrm{C}$ and $37^{\circ} \mathrm{C}$; (a) Isolates from water and (b) Isolates from sediment

and 6-13 (Table 1), respectively. Majority of isolates from sediment samples, i.e., more than $50 \%$ of the total isolates showed wide range of $\mathrm{pH}$ tolerance (Table 2). Fifty-four percentage showed growth at $\mathrm{pH}$ range $2-13,43 \%$ at $\mathrm{pH}$ range 3 -
13 and only $2.5 \%$ at $\mathrm{pH}$ range $5-13$. Growth was not observed at $\mathrm{pH}$ range 4-11 and 6-11 (Table 2). When analysed statistically, no significant difference was found in the growth of isolates collected from water and sediment at different $\mathrm{pH}$ ranges. Strains having a 
Table 2 : Effect of $\mathrm{pH}$ and salinity on growth of cold adapted bacteria isolated from sediment of Kongsfjord

\begin{tabular}{|c|c|c|c|c|c|c|c|c|c|}
\hline Stations & $\begin{array}{l}\text { Isolate } \\
\text { No. }\end{array}$ & Identity & $\mathrm{pH}$ & $\begin{array}{l}\mathrm{NaCl} \\
\text { tolerance (M) }\end{array}$ & Stations & $\begin{array}{l}\text { Isolate } \\
\text { No. }\end{array}$ & Identity & $\mathrm{pH}$ & $\begin{array}{l}\mathrm{NaCl} \\
\text { tolerance (M) }\end{array}$ \\
\hline \multirow[t]{17}{*}{ Station 1} & & & & & Station 3 & & & & \\
\hline & 1 & Staphylococcus & $3-13$ & 0.5 & & 40 & Micrococcus & $3-13$ & 2 \\
\hline & 2 & Bacillus & $3-13$ & 3.5 & & 41 & Staphylococcus & $2-13$ & 2.5 \\
\hline & 3 & Moraxella & $3-13$ & 0.5 & & 42 & Staphylococcus & $2-13$ & 2.5 \\
\hline & 4 & Micrococcus & $2-13$ & 2 & & 43 & Micrococcus & $2-13$ & 2.5 \\
\hline & 5 & Coryneforms & $3-13$ & 3.5 & & 44 & Micrococcus & $2-13$ & 3.5 \\
\hline & 6 & Micrococcus & $3-13$ & 3.5 & & 45 & Bacillus & $3-13$ & 3.5 \\
\hline & 7 & Staphylococcus & $3-13$ & 2.5 & & 46 & Bacillus & $2-13$ & 1.5 \\
\hline & 8 & Micrococcus & $3-13$ & 3.5 & & 47 & Staphylococcus & $2-13$ & 1 \\
\hline & 9 & Bacillus & $2-13$ & 1 & & 48 & Staphylococcus & $3-13$ & 2 \\
\hline & 10 & Moraxella & $5-13$ & 3 & & 49 & Staphylococcus & $2-13$ & 2.5 \\
\hline & 11 & Aeromonas & $5-13$ & 0.5 & & 50 & Staphylococcus & $2-13$ & 2 \\
\hline & 12 & Coryneforms & $4-13$ & 2 & Station 4 & & & & \\
\hline & 13 & Moraxella & $4-13$ & 0.5 & & 51 & Micrococcus & $2-13$ & 3.5 \\
\hline & 14 & Coryneforms & $4-13$ & 4 & & 52 & Staphylococcus & $2-13$ & 3.5 \\
\hline & 15 & Micrococcus & $2-13$ & 1 & & 53 & Staphylococcus & $2-13$ & 3.5 \\
\hline & 16 & Micrococcus & $3-13$ & 3 & & 54 & Staphylococcus & $2-13$ & 3.5 \\
\hline \multirow[t]{21}{*}{ Station 2} & & & & & & 55 & Coryneforms & $3-13$ & 2 \\
\hline & 17 & Coryneforms & $2-13$ & 2.5 & & 56 & Coryneforms & $3-13$ & 1 \\
\hline & 18 & Pseudomonas & $2-13$ & 2 & & 57 & Coryneforms & $3-13$ & 3.5 \\
\hline & 19 & Coryneforms & $3-13$ & 2.5 & & 58 & Coryneforms & $3-13$ & 3.5 \\
\hline & 20 & Coryneforms & $3-13$ & 2 & & 59 & Cytophaga/Flavobacteria & $2-13$ & 1.5 \\
\hline & 21 & Coryneforms & $2-13$ & 3.5 & & 60 & Micrococcus & $2-13$ & 3.5 \\
\hline & 22 & Coryneforms & $2-13$ & 3 & & 61 & Coryneforms & $2-13$ & 3 \\
\hline & 23 & Coryneforms & $2-13$ & 2 & & 62 & Coryneforms & $2-13$ & 0.5 \\
\hline & 24 & Micrococcus & $2-13$ & 2.5 & & 63 & Coryneforms & $3-13$ & 2 \\
\hline & 25 & Micrococcus & $3-13$ & 2.5 & & 64 & Coryneforms & $2-13$ & 2 \\
\hline & 26 & Micrococcus & $3-13$ & 3 & & 65 & Streptococcus & $3-13$ & 2 \\
\hline & 27 & Micrococcus & $2-13$ & 2 & & 66 & Coryneforms & $2-13$ & 2 \\
\hline & 28 & Micrococcus & $2-13$ & 2 & & 67 & Coryneforms & $2-13$ & 4 \\
\hline & 29 & Staphylococcus & $2-13$ & 1 & & 68 & Staphylococcus & $3-13$ & 0.5 \\
\hline & 30 & Staphylococcus & $2-13$ & 1 & & 69 & Micrococcus & $2-13$ & 2 \\
\hline & 31 & Coryneforms & $3-13$ & 3 & & 70 & Micrococcus & $3-13$ & 3.5 \\
\hline & 32 & Staphylococcus & $3-13$ & 1 & & 71 & Staphylococcus & $2-13$ & 2 \\
\hline & 33 & Coryneforms & $2-13$ & 1 & & 72 & Staphylococcus & $2-13$ & 3 \\
\hline & 34 & Staphylococcus & $2-13$ & 2 & & 73 & Staphylococcus & $3-13$ & 3 \\
\hline & 35 & Micrococcus & $2-13$ & 1 & & 74 & Coryneforms & $2-13$ & 0.5 \\
\hline & 36 & Micrococcus & $3-13$ & 1 & & 75 & Staphylococcus & $3-13$ & 2 \\
\hline \multirow[t]{4}{*}{ Station 3} & & & & & & 76 & Coryneforms & $2-13$ & 2 \\
\hline & 37 & Micrococcus & $2-13$ & 2.5 & & 77 & Coryneforms & $3-13$ & 3 \\
\hline & 38 & Staphylococcus & $3-13$ & 2.5 & & 78 & Coryneforms & $2-13$ & 4 \\
\hline & 39 & Micrococcus & $2-13$ & 2.5 & & 79 & Coryneforms & $3-13$ & 3.5 \\
\hline
\end{tabular}

wide $\mathrm{pH}$ range (2-11) for growth has earlier been reported (Srinivas et al., 2009). Reddy et al. (2009) reported that a good proportion of bacterial isolates from sediments collected from a melt water stream from Midtre Lovenbreen glacier, Kongsfjord, could grow at a narrow $\mathrm{pH}$ range (5-7). In the study, none of the isolates collected from sediment samples showed growth at narrow $\mathrm{pH}$ range.
Majority of isolates from water and sediment were halophilic in nature, tolerating $\geq 0.5 \mathrm{M} \leq 4 \mathrm{M} \mathrm{NaCl}$ (Table 1, 2). The salinity tolerance of isolates from water samples was $2.5 \mathrm{M}$ for $14 \%, 3 \mathrm{M}$ for $54 \%, 3.5 \mathrm{M}$ for $14 \%, 4 \mathrm{M}$ for $17 \%$ and $4.5 \mathrm{M}$ for $2 \%$ isolates from different stations, none of the isolates could grow below $2.5 \mathrm{M}$ salinity. The salinity tolerance was $0.5 \mathrm{M}$ for $8 \%, 1 \mathrm{M}$ for $15 \%, 1.5 \mathrm{M}$ for $2.5 \%, 2 \mathrm{M}$ for $25 \%, 2.5 \mathrm{M}$ for another $15 \%, 3 \mathrm{M}$ 
for $10 \%, 3.5 \mathrm{M}$ for $20 \%$ and $4 \mathrm{M}$ for $4 \%$ of isolates of sediment samples collected from different stations. There was no significant difference in the salinity tolerance of the isolates from water and sediment (P-value $>0.05)$. The ability of the bacterial isolates to tolerate wide range of salinity helps them to survive the fluctuating salinity of their habitat, while melting and freezing process of seawater.

Nearly all the isolates from water produced at least one enzyme at $4{ }^{\circ} \mathrm{C}$ and $/$ or $37^{\circ} \mathrm{C}$. Thirty three percent of the isolates from four stations produced gelatinase at $4{ }^{\circ} \mathrm{C}$ and $65 \%$ at $37^{\circ} \mathrm{C}$. Lipase production at $4{ }^{\circ} \mathrm{C}$ was shown by $60 \%$ of isolates and at 37 ${ }^{\circ} \mathrm{C}$ by $100 \%$ of isolates. Seven percent of the isolates showed amylase production at $4{ }^{\circ} \mathrm{C}$ and $70 \%$ at $37^{\circ} \mathrm{C}$. Among the isolates of sediment samples from four stations, $68 \%$ showed gelatinase activity at $4{ }^{\circ} \mathrm{C}$ and $80 \%$ at $37^{\circ} \mathrm{C}$. Majority of the isolate showed lipolytic activity at both the temperatures. Lipolytic activity at $4{ }^{\circ} \mathrm{C}$ was shown by $83 \%$ of the isolates and at $37^{\circ} \mathrm{C}$ by $97 \%$ of the isolates. Amylase activity at $4{ }^{\circ} \mathrm{C}$ was shown by $21.5 \%$ of isolates and at $37{ }^{\circ} \mathrm{C}$ by $38 \%$ of isolates. In several studies, the temperature dependence of enzyme production during growth of isolates from polar water has previously been reported (Zeng et al., 2003; Groudieva et al., 2004; Martınez-Rosales and Susana, 2011).

On comparing the enzyme production capability of isolates collected from water and sediment samples, majority of them showed production at $37^{\circ} \mathrm{C}$ than at $4{ }^{\circ} \mathrm{C}$ (Fig 2a, 2b). The sediment isolates exhibited significant difference in the production of each of the enzymes at $37^{\circ} \mathrm{C}$ and $4{ }^{\circ} \mathrm{C}(\mathrm{P}$-value $<$ 0.01). However, water isolates did not show any such significant difference ( $P$-value $>0.05$ ). Comparison of enzyme production by sediment and water isolates at $4{ }^{\circ} \mathrm{C}$ showed that the production was more by sediment isolates when compared with those from water. However, the difference was not statistically significant (Pvalue $=0.3$ ). At $37^{\circ} \mathrm{C}$ in contrary isolates from water produced more enzymes than from sediment, except for gelatinase enzyme, which was produced more by sediment isolates. When analysed by two-way ANOVA, this source wise variation in enzyme production at $37^{\circ} \mathrm{C}$ was however not significant ( $P$-value $=0.1$ ). Arnosti (2008) previously reported contrasting pattern of enzymatic hydrolysis between isolates in water and sediment. The hydrolytic enzyme production in sediment isolates are known to be influenced mainly by the availability of organic matter (Vetter and Deming, 1999)

The ability of psychrophiles/psychrotrophs to survive in the cold environments is mainly dependent on their ability to synthesize cold adapted enzymes (Kuddus, 2015). Psychrophilic organisms with potential application in biotechnology, agriculture and medicine have attracted the attention of the scientific community (Gerday, 2000; Podar and Reysenbach, 2006; Huston, 2007). Enzymes from psychrotrophs with high thermostability, high salinity tolerance and ability to grow in wide range of $\mathrm{pH}$ makes them potential candidates for various industrial and biotechnological processes (Tanaka et al., 2012; Qin et al., 2014; Tchigvintsev et al., 2015). More specifically, cold active proteases and amylases can be used in detergent, leather, textile and pharmaceutical industries (Gupta et al., 2002; Singhal et al., 2012; Chattopadhyay et al., 2013). Major application of heat labile lipases is as biocatalysts when thermo sensitive compounds are used and in laundry applications (Marx et al., 2004).

In conclusion, all the isolates produced one or more enzymes; amylase, lipase or protease at $4{ }^{\circ} \mathrm{C}$ and (or) $37^{\circ} \mathrm{C}$ and showed growth at wide range of $\mathrm{pH}$ and exhibited high salinity tolerance. Thus, the bacteria from water and sediments of Kongsford are a potential source for novel hydrolytic enzymes, especially lipase.

\section{Acknowledgments}

The authors would like to thank the Director, National Centre for Antarctic and Ocean Research and the Ministry of Earth Sciences, Government of India for the financial and logistic support for the Arctic expedition.

\section{References}

Arnosti, C.: Functional differences between Arctic seawater and sedimentary microbial communities: Contrasts in microbial hydrolysis of complex substrates. FEMS Microbiol. Ecol., 66, 343-351 (2008).

Bayles, D.O., B.A. Anous and B.J. Wilkinson: Cold stress proteins induced in Listeria monocytogenes in response to temperature downshock and growth at low temperatures. App. Environ. Microbiol., 62, 1116-1119(1996).

Chattopadhyay, A.N., P. Singh, A. Dey, P. Roy, S. Chatterjee, P. Saha and S.K. Mukhopadhyay: Study of a psychrotolerant amylolytic Paenibacillus sp. isolated from Arctic region. J. Microbiol. Biotechnol. Res., 3, 24-31(2013).

Feller, G. and C. Gerday: Psychrophilic enzymes: Hot topics in cold adaptation. Nat. Rev. Microbiol., 1, 200-208 (2003).

Gerday, C.: Cold-adapted enymes: from fundamentals to biotechnology. Trends Biotechnol., 18, 103-107 (2000).

Groudieva, T., M. Kambourova, H. Yusef, M. Royter, R. Grote, H. Trinks and G. Antranikian: Diversity and cold-active hydrolytic enzymes of culturable bacteria associated with Arctic Sea ice, Spitzbergen. Extremophiles, 8, 475-488 (2004).

Gupta, R., Q.K. Beg and P. Lorenz: Bacterial alkaline proteases: Molecular approaches and industrial applications. Appl. Microbiol. Biotechnol., 59, 15-32 (2002).

Hatha, A.A. M., K.M. Mujeeb Rahiman, K.M. Deepu Lal, K.P. Krishnan, S. Rupesh Kumar and A.V. Saramma: Impact of climate change on 
heterotrophic bacterial communities in the water and sediment of Kongsfjord in Norwegian Arctic. In: Climate change and Himalayan informatics (Eds.: J. Sundaresan and P. Guptha). Scientific Publishers, India, pp. 170-182 (2013).

Helmke, E. and H. Weyland: Psychrophilic versus psychrotolerant bacteria: Occurrence and significance in polar and temperate marine habitats. Cell Mol. Biol., 50, 553-561 (2004).

Hoover, R.B. and E.V. Pikuta: Psychrophilic and psychrotolerant microbial extremophiles in polar environment. Polar Microbiology (Eds.: K.B. Asim, J. Aislabie and R.M. Atlas): CRES Press, pp. 115$156(2010)$

Hop, H., T. Pearson and N.E. Hegseth: The marine ecosystem of Kongsfjorden, Svalbard. Polar Res., 21, 167-208 (2002)

Huston, A. L.: Biotechnological aspects of cold adapted enzymes. In: Psychrophiles: From biodiversity to biotechnology (Eds.: R. Margesin, F. Schinner, J.C. Marx and E. Gerday). Springer, p. 347364 (2007).

Jankowska, K., M. Wlodarska-Kowalczuk and P. Wieczorek: Abundance and biomass of bacteria in two Arctic glacial fjords. Pol. Res., 26, 77-84 (2005).

Kuddus, M.: Cold-active microbial enzymes. Biochem. Physiol., 4, 132 (2015).

Martınez-Rosales, C. and S. Castro-Sowinski: Antarctic bacterial isolates that produce cold-active extracellular proteases at low temperature but are active and stable at high temperature. Polar Res., 30, 7123 (2011).

Marx, J.C., V. Blaise, T. Collins, S. D'Amico, D. Delille, E. Gratia, A. Hoyoux, A.L. Huston, G. Sonan, G. Feller and C. Gerday: A perspective on cold enzymes: Current knowledge and frequently asked questions. Cell. Mol. Biol., 50, 643-655 (2004).

Michel, V., I. Lehoux, G. Depret, P. Anglade, J. Labadie and M. Hebraud: The cold shock response of the psychrotrophic bacterium Pseudomonas fragi involves four low-molecular-mass nucleic acid-binding proteins. J. Bacteriol., 179, 7331-7342 (1997).

Morita, R.Y.: Psychrophilic bacteria. Bacteriol. Rev., 39, 167 (1975).

Neethu, C.S., K.M. Mujeeb Rahiman, K.P. Krishnan, A.V. Saramma and A.A.M. Hatha: Substrate specificity of cold active lipases of psychrotrophic bacteria from Kongsfjord and its partial characterization. Adv. Biotech., 12, 28-31 (2012).

Neethu, C.S., K.M. Mujeeb Rahiman, A.V. Saramma and A.A.M. Hatha: Heavy metal resistance in Gram-negative bacteria isolated from Kongsfjord, Arctic. Can. J. Microbiol., 61, 429-435 (2015).

Podar, M. and A. Reysenbach: New opportunities revealed by biotechnological explorations of extremophiles. Curr. Opin. Biotech., 17, 250-255 (2006).

Prasad, S., B.P. Manasa, B. Sailaja, B.Z. Preethi, Sivaramakrishnan, Rajan and S. Shivaji: Diversity and bioprospective potential (coldactive enzymes) of cultivable marine bacteria from the subarctic glacial fjord, Kongsfjorden. Curr. Microbiol., 68, 233-238 (2014).

Qin, Y., Z. Huang and Z. Liu: A novel cold-active and salt-tolerant aamylase from marine bacterium Zunongwangia profunda:
Molecular cloning, heterologous expression and biochemical characterization. Extremophiles, 18, 271-281 (2014).

Rasol, R., A.R. Rashidah, N.R. Sitinur, J. Smykla, W.O. Wan Maznah and S.A. Alias: Psychrotrophic lipase producers from Arctic soil and sediment samples. Pol. J. Microbiol., 63, 75-82 (2014).

Reddy, P.V.V., S.S.N. Rao, M.S. Pratibha, B. Sailaja, B. Kavya, R.R. Manorama, S.M. Singh, T.N.R. Srinivas and S. Shivaji: Bacterial diversity and bioprospecting for cold-active enzymes from culturable bacteria associated with sediment from a melt water stream of Midtre Lovénbreen glacier, an Arctic glacier. Res. Microbiol., 160, 538-546 (2009).

Shukor, M.Y., N.A.A. Hassan, A.Z. Jusoh, N. Perumal, N.A. Shamaan, W.P. MacCormack and M.A. Syed: Isolation and characterization of a Pseudomonas diesel-degrading strain from Antarctica. J. Environ. Biol., 30, 1-6 (2009).

Singhal, P., K.V. Nigam and S.A. Vidyarthi: Studies on production, characterization and applications of microbial alkaline protease. Intl. J. Adv. Biotec. Res., 3, 653-669 (2012).

Srinivas, T.N.R., S.S.N. Rao, P.V.V. Reddy, M.S. Pratibha, B. Sailaja, B. Kavya, H.K. Kishore, Z. Begum, S.M. Singh and S. Shivaji: Bacterial diversity and bioprospecting for cold-active lipases, amylases and proteases from culturable bacteria of Kongsfjorden and Ny-Ålesund, Svalbard, Arctic. Curr. Microbiol., 59, 537-547 (2009).

Tanaka, D., S. Yoneda, Y. Yamashiro, A. Sakatoku, T. Kayashima, K. Yamakawa and S. Nakamura: Characterization of a new coldadapted lipase from Pseudomonas sp. TK-3. Appl. Biochem. Biotechnol., 168, 327-338 (2012).

Tan, T.L. and H.J. Ruger: Biomass and nutritional requirements of psychrotrophic bacterial communities in Fram Strait and Western Greenland Sea. Kiel. Meeresforsch. Sonder., 8, 219-224 (1991).

Tchigvintsev, A., H. Tran, A. Popovic, F. Kovacic, G. Brown, R. Flick, M. Hajighasemi, O. Egorova, J.C. Somody, D. Tchigvintsev, A. Khusnutdinova, T.N. Chernikova, O.V. Golyshina, M.M. Yakimov, A. Savchenk, P.N. Golyshin, K.E. Jaeger and A.F. Yakunin: The environment shapes microbial enzymes: five cold-active and saltresistant carboxylesterases from marine metagenomes. Appl. Microbiol. Biotechnol., 99, 2165-2178 (2015).

Teske, A., A. Durbin, K. Ziervogel, C. Cox and C. Arnosti: Microbial community composition and function in permanently cold seawater and sediments from an Arctic fjord of Svalbard. Appl. Environ. Microbiol., 77, 2008-2018 (2011).

Vetter, Y.A. and J.W. Deming: Growth rates of marine bacterial isolates on particulate organic substrates solubilized by freely released extracellular enzymes. Microb. Ecol., 37, 86-94 (1999).

Wlodarska-Kowalczuk, M. and J.M. Weslawski: Impact of climate warming on Arctic benthic biodiversity: A case study of two Arctic glacial bays. Clim. Res., 18, 127-132 (2001)

Zeng, R., R. Zhang, J. Zhao and N. Lin: Cold-active serine alkaline protease from the psychrophilic bacterium Pseudomonas strain DY-A: enzyme purification and characterization. Extremophiles, 7, 335-337 (2003). 